\title{
ДИскУССИИ
}

www.volsu.ru

DOI: https://doi.org/10.15688/jvolsu2.2020.4.14

UDC 81'42:347.781.55

Submitted: 12.08 .2019

LBC 81.055.51.3

Accepted: 28.04.2020

\section{INFORMATION DOCUMENTS OF EXECUTIVES: PROBLEMS OF IDENTIFICATION AND DESCRIPTION ${ }^{1}$}

\author{
Mariya A. Shirinkina \\ Perm State National Research University, Perm, Russia
}

\begin{abstract}
The article considers the system of information documents of the executives. It is shown that genre forms used in public administration for the purpose of informing are numerous. Many of these forms lack clear genre nominations, which explains the fact that researchers substitute genre nominations by names of the issues in which the informative documents are published. The author characterizes the information genres, which are in major demand with state administration: public report, press release and briefing materials. The article reveals that public report reflects information about the officials' actions or about the actual state of affairs with the relevant government agency; by its structure, it is a standardized text with language units typical of business communication. Press release is a short message about productive work of the authorities, aimed at shaping their positive image; its distinguishing feature is the use of emotionally and expressively colored lexical units and stylistic expressive means. The genre of briefing materials, along with the key objective - to inform, employs an additional setting for popularization of legal information, and hence a wide range of visual tools (tables, charts, flowcharts, fonts, colours, etc.). The author assumes that the contents and the instructive appeal of certain fragments of information genres make them close to the enacting documents genres, although their means of expressing style features are different.

Key words: discourse, written discourse of executive authorities, document, informative documents, genre, public report, press release, briefing materials.

Citation. Shirinkina M.A. Information Documents of Executives: Problems of Identification and Description. Vestnik Volgogradskogo gosudarstvennogo universiteta. Seriya 2. Yazykoznanie [Science Journal of Volgograd State University. Linguistics], 2020, vol. 19, no. 4, pp. 157-169. (in Russian). DOI: https://doi.org/10.15688/ jvolsu2.2020.4.14
\end{abstract}

УДК $81^{\prime} 42: 347.781 .55$

Дата поступления статьи: 12.08.2019

ББК 81.055 .51 .3

Дата принятия статьи: 28.04.2020

\section{ИНФОРМАЦИОННЫЙ ТИП ДОКУМЕНТОВ ИСПОЛНИТЕЛЬНОЙ ВЛАСТИ: ПРОБЛЕМЫ ВЫДЕЛЕНИЯ И ОПИСАНИЯ ${ }^{1}$}

\author{
Мария Андреевна Ширинкина \\ Пермский государственный национальный исследовательский университет, г. Пермь, Россия
}




правовой информации, что обусловливает широкое употребление визуальных средств - таблиц, диаграмм, рисунков, блок-схем, шрифта, цвета и др. Определено, что содержание и инструктивная направленность отдельных фрагментов информационных жанров сближают их с жанрами предписательных документов, однако средства выражения стилевой специфики в тех и других различаются.

Ключевые слова: дискурс, письменный дискурс исполнительной власти, документ, информационные документы, жанр, публичный отчет, пресс-релиз, информационные материалы.

Цитирование. Ширинкина М. А. Информационный тип документов исполнительной власти: проблемы выделения и описания // Вестник Волгоградского государственного университета. Серия 2, Языкознание. - 2020. - Т. 19, № 4. - С. 157-169. - DOI: https://doi.org/10.15688/jvolsu2.2020.4.14

\section{Введение}

Традиционно при классификации документных текстов большинство специалистов указывает среди гражданско-правовых, организационно-правовых, распорядительных, финансовых, учетных, документов по личному составу и личных класс информационно-справочных документов. Однако вопрос его жанрового наполнения решается исследователями по-разному. Например, Н.Н. Кушнаренко называет информационно-справочными документами доклады, отчеты, докладные и пояснительные записки, справки, сводки, обзоры, некоторые виды служебных писем [Кушнаренко, 2006, с. 345]; С.П. Кушнерук - протоколы, акты, сводки, справки, заключения [Кушнерук, 2008, с. 57]; Н.Н. Куняев - протоколы, акты, справки, служебные письма (см.: [Куняев, Уралов, Фабричнов, 2012, с. 128]).

Выполняя в государстве функцию управления, органы исполнительной власти готовят разные информационные документы (отчеты, объявления, извещения, пресс-релизы) и тексты информационной направленности (листовки, брошюры, бюллетени, буклеты). Специалисты по политологии и теории PR отмечают, что разнообразие форм информационной работы и каналов распространения сообщений направлено на удовлетворение информационных потребностей различных целевых групп, что в свою очередь влияет на результативность информационной политики органа власти, а следовательно, определяет эффективность государственного управления [Илатовская, 2007, с. 16-17; Мозолин, 2012, с. 11].

При этом информационные речевые произведения, в широком смысле ориентированные на информирование, в действительности выполняют массу специальных функций (например, просвещения, разъяснения, создания позитивного имиджа власти) и имеют формально-содержательные отличия. Разные документоведческие подходы к типологии деловых бумаг, а также широкий ассортимент информационно-справочных и PR-текстов и их многофункциональность, с одной стороны, затрудняют создание конечного списка текстов этого типа - жанров, но, с другой стороны, определяют существование весьма интересного объекта для исследования. Неслучайно в последнее время появляются работы, посвященные информационным жанрам делового общения [Белоконева, 2012; Быстрова, 2017; Киреева, 2015] и текстам PR-коммуникации [Анисимова, 2015; Буслаева, 2015].

В фокусе внимания в исследовании находятся жанры письменного дискурса исполнительной власти, который мы определяем как особую разновидность использования языка в когнитивно-коммуникативной деятельности должностных лиц органов исполнительной власти при осуществлении ее функций (государственного управления, правотворчества, правоприменения, контроля и надзора и др.), детерминируемую условиями общения исполнительной власти с различными субъектами и выражаемую в целостной системе жанров (обоснование понятия см. в: [Ширинкина, 2017]). В соответствии с ведущей авторской интенцией в составе указанного дискурса можно выделить три группы жанров: предписательные, эпистолярные и информационные (к числу которых мы относим и тексты сфеpы PR). Цель данной статьи - определить примерный состав письменных информационных документов, созданных органами исполнительной власти, и охарактеризовать наиболее востребованные из них.

При обращении к массиву информационных документов исследователь сталкивается с проблемами их жанровой верифика- 
ции. У многих из этих текстов отсутствует жанровое обозначение, в связи с чем возможна подмена понятия «жанр» понятием «носитель информации». Аналогичные проблемы возникают в сфере рекламы и PR (см. об этом, например: [Анисимова, 2018; Богоявленский, 2004; Имшинецкая, 2002]). По справедливому замечанию И.А. Имшинецкой, «жанр и рекламоноситель соотносятся как форма и содержание - форму рекламоносителя можно наполнить разными жанрами» [Имшинецкая, 2002, с. 8]. Развивая рассуждения И.А. Имшинецкой, Т.В. Анисимова пишет: «Каждый рекламоноситель задает использование своей системы жанровых форм, характерных для размещаемых там текстов» [Анисимова, 2018, c. 161].

Учитывая тот факт, что многие из текстов относятся к сфере PR, логичным представляется изучение работ в данной области. Так, один из основателей петербургской школы PR A.Д. Кривоносов, принимая во внимание своеобразие продуктов PR-коммуникации, предлагает разграничивать жанровую типологию речевых произведений этой сферы и их классификацию по разным признакам, в том числе по критерию «сложность текста», на основании которого выделяет простые и комбинированные PR-тексты. Простой PR-текст, по словам исследователя, - «это конкретный текст как определенная, отграниченная от других текстов данность, существующая в пространстве PR-коммуникаций как самостоятельная и самодостаточная» [Кривоносов, 2002, с. 78]. К простым текстам PR-коммуникации автор относит следующие жанровые разновидности: пресс-релиз, приглашение, биографию, заявление для СМИ и т. д. Комбинированный PR-текст - «это макротекст, представляющий “набор" первичных простых текстов, объединенных общей тематикой (новостным поводом)», «механическая или полиграфическая комбинация простых PR-текстов» [Кривоносов, 2002, с. 78]. В класс комбинированных PR-текстов ученый включает пресс-кит, проспект, брошюру, буклет, ньюслеттер и листовку.

Иными словами, понятие жанра, традиционно определяемое в жанроведении как относительно устойчивый тематический, ком- позиционный и стилистический тип высказываний [Бахтин, 1986, с. 254-255], можно использовать и по отношению к речевым продуктам, предназначенным для связей с общественностью. При этом брошюры, листовки, буклеты, по нашему мнению, целесообразно считать полиграфическими формами, или, в терминологии процитированных выше авторов, «носителями информации». Одни из них, например брошюры и буклеты, содержат целостный текст, которому, как правило, сложно присвоить какое-то жанровое название. Составители называют эти тексты информационными материалами, методическими рекомендациями, официальной информацией и т. д. Как указано в одном из таких изданий, в них приводятся «адаптированные нормативные материалы», «методические материаль» (Управление..., с. 2), поясняющие законодательно закрепленные процедуры выполнения тех или иных правовых действий. Бюллетени, в отличие от брошюр и буклетов, являются сборниками из нескольких текстов. Бюллетени бывают официальными, содержащими нормативные акты органов исполнительной власти, не относящиеся к разряду информационно-справочных документов, и информационными, включающими анонсы, пресс-релизы и тексты отчетных речей должностных лиц. Назначение и целевую аудиторию издательской продукции подобного рода эксплицирует характерная надпись: Использование материалов «Информационного бюллетеня» приветствуется. Ссылка на «Информачионный бюллетень» - не обязательна (Информационный бюллетень...). Очевидно, что надпись строится на основе стандартных для такого случая фраз: Копирование, распространение, перепечатка материала без письменного разрешения автора не допускается. При использовании материала ссылка на источник обязательна, выражает противоположное им значение и указывает на то, что издание предназначено для широкого распространения информации через СМИ и общественные организации. Такие бюллетени могут быть напечатаны или размещены в электронной форме на официальном сайте, благодаря чему круг их адресатов максимально расширяется. 
Кроме проблемы разграничения жанра и носителя информации, перед исследователем стоит еще одна проблема - невозможность составления исчерпывающего перечня жанровых разновидностей документов информационного типа. При обращении к конкретным текстам оказывается, что информационный текстотип документов исполнительной власти представлен богатой жанровой палитрой, в которой можно выделить, например, отчеты должностных лиц о работе подразделений властных органов, объявления, заключения, извещения, пресс-релизы, памятки и др. На практике можно заметить, что схожие по теме, композиции и стилистическим чертам типы текстов обозначаются составителями с помощью разных (как правило, синонимичных) жанровых наименований, например: сообщение / информация / официальная информачия / извещение. Эти тексты размещаются в электронном формате в справочных правовых системах типа «КонсультантПлюс» (http://www.consultant.ru/) или «Государственной системе правовой информации» (http://pravo.gov.ru/), на официальных сайтах органов исполнительной власти и в печатном виде на информационных стендах в помещениях органов власти, а также в составе официальных бюллетеней, издаваемых органами исполнительной власти разного уровня. Таким образом, возникает необходимость унификации жанровых наименований информационных текстов, что, по нашему мнению, значительно облегчит поиск документов определенного жанра в указанных информационно-коммуникационных источниках.

\section{Материал и методы исследования}

Жанр понимается нами, вслед за М.М. Бахтиным, как относительно устойчивый тип высказывания, отличающийся тематическими, композиционными и стилистическими особенностями [Бахтин, 1986, с. 254-255]. По отношению к говорящему / пишущему жанр - это модель речевого поведения в типичных коммуникативных ситуациях разных сфер духовной деятельности человека. Результативно жанр является моделью построения целого текста, а также типом текста с характерными для него языковыми средствами. При этом жанровый текстотип тесно связан с жизненной ситуацией - экстралингвистическим контекстом. Таким образом, полный анализ жанра как типа текстов можно получить лишь учитывая, наряду с его языковыми особенностями, ту жизненную ситуацию, в которой этот текст образуется и функционирует.

Исходя из этого, анализ жанровых текстотипов информационных документов исполнительной власти производится по следующему алгоритму: 1) с опорой на коммуникативную ситуацию определяются автор и адресат текста, а также коммуникативная интенция говорящего; 2) с использованием словарных дефиниций из терминологических словарей по документоведению устанавливается жанр анализируемого текста; 3) с учетом положений функциональной стилистики описываются стилевые черты каждого жанра и характерные для него вербальные и невербальные средства выражения этих стилевых черт.

В статье представлены тексты трех социально значимых жанров сферы государственного управления - публичного отчета, пресс-релиза и информационных материалов. В качестве источников использованы печатные брошюры информационно-справочной и методической направленности, а также электронные документы, размещенные на официальных сайтах органов исполнительной власти и местного самоуправления, в частности администраций города Архангельска, Волгограда, Перми и Санкт-Петербурга, в период с 2009 по 2019 год.

\section{Результаты и обсуждение}

Учитывая, с одной стороны, жанровое разнообразие информационных документов исполнительной власти, с другой - ограниченность объема статьи, представим характеристику трех востребованных жанров указанной направленности - публичного отчета, прессрелиза и так называемых информационных материалов.

\section{Публичный отчет}

Традиционно в делопроизводстве отчет определяется как «документ, содержащий сведения об итогах выполнения планов, заданий, командировок и других мероприятий, 
представляемый вышестоящей организации (органу власти) или вышестоящему должностному лицу» (Словарь видов..., с. 52). В современной деловой коммуникации получил широкое распространение жанр публичного отчета, который размещается на официальном сайте организации, является «инструментом в сфере связей с общественностью, предназначенным прежде всего для внешней аудитории (партнеров, клиентов, органов власти и т. д.), реализует требование информационной открытости и осуществляет презентацию организации, информируя о разных направлениях ее деятельности и роли в социуме» [Буслаева, 2015, с. 12]. Составителем отчета выступает конкретное должностное лицо. Адресатом становятся все посетители сайта, в том числе и журналисты, которые на основе этих данных могут написать новостные тексты для СМИ. Наряду с информирующей, любой отчет выполняет имиджеформирующую и контролирующую функции, поскольку позволяет вышестоящим должностным лицам и общественности проконтролировать деятельность отчитывающегося лица или органа власти. Содержанием рассматриваемого делового жанра оказывается информация о реальном состоянии дел, проблемах и достижениях, действиях и мероприятиях, проведенных должностным лицом или подразделением органа власти. По структуре публичный отчет - это стандартизированный текст, часто оформленный в таблице.

Приведем фрагмент отчета комитета по образованию города Архангельска:

За 2017-2018 учебный год увеличилось количество объединений военно-патриотического направления: 45 объединений функционирует на базе ОО и 31 объединение-в УДО, в них заняты 3702 учащихся. Также активно развивается техническое творчество: 54 объединения созданы на базе ОO, 36 - на базе УДО, из них 7 объединений робототехники. Техническим творчеством занимаются 3033 учащихся. Популярным остается и туристско-краеведческое направление: в 66 объединениях, созданных на базе ОО и в УДО, занимаются 1602 учащихся, которые активно путешествуют по Архангельской области и занимаются изучением родного края (Coстояние и результативность..., с. 10).

Как видим, в отчете доминирует тональность констатации, создаваемая на грамма- тическом уровне глаголами и причастиями настоящего и прошедшего времени в значении констатации, многочисленными цифровыми показателями, отражающими фактологически точные данные.

Информация в жанре отчета передается официальным тоном, при этом можно заметить весьма частое употребление в отчетах средств выражения оценки (активно, популярныц, эффективный, комфортные условия, наиболее привлекательный и пр.) и лексем с семантикой интенсивности (увеличиваться / увеличение, расширяться / расширение, повышаться / повышение и т. п.). Эти языковые единицы формируют аналитическую направленность текста, поскольку данные в нем представляются, как правило, в сравнительном аспекте по отношению к предыдущему отчетному периоду и, кроме того, отражают тенденции развития органа власти и соответствующего региона, воспроизводят прогнозы и перспективы изменений и нововведений. При этом подавляющее большинство языковых единиц имеет общее значение продуктивности, результативности.

В жанровом отношении отчет сближается с обзором, который понимается как «документ, составленный в целях информирования подведомственных и иных организаций о результатах работы в той или иной области или о деятельности той или иной группы организаций за определенный период» (Словарь видов..., с. 48). Предполагается, что в отчете должна быть отражена именно деятельность отчетного лица или органа, а в обзоре - представлен сравнительный анализ, прослежена динамика развития объекта (региона или страны в целом), которая стала возможна благодаря действиям властных структур. Подчеркнем, что на сайтах органов исполнительной власти можно найти документы то с одним, то с другим жанровым наименованием. Как правило, эти документы совмещают в себе черты отчета и обзора.

\section{Пресс-релиз}

Следующий жанр, посредством которого органы исполнительной власти информируют общественность, - пресс-релиз. В теории PR пресс-релиз определяют как «основной 
жанр PR-текста, содержащий актуальную для прессы оперативную информацию о событии, связанном с базисным субъектом PR» [Кривоносов, 2002, с. 131], в нашем случае - о деятельности органов исполнительной власти или отдельных должностных лиц.

Автором пресс-релиза выступает специалист по связям с общественностью конкретного органа исполнительной власти. Исследователи разграничивают пресс-релизы по признаку адресата, выделяя профильные (ориентированные на профессиональную аудиторию) и общие (ориентированные на широкие группы целевых аудиторий) [Тихомирова, 2008, с. 63]. К последним относятся тексты, размещенные на официальных сайтах органов исполнительной власти, хотя, безусловно, в зависимости от темы каждый из них преимущественно привлекает внимание определенной целевой группы.

Основной функцией этой жанровой формы является оперативная передача информации о положительных событиях в деятельности должностных лиц и органов исполнительной власти, направленная на формирование их позитивного имиджа.

По признаку оперативности информирования пресс-релизы подразделяют на релизанонсы и ньюс-релизы, первые сообщают о будущем событии, вторые появляются после освещаемого события и информируют об итогах состоявшегося события [Кривоносов, 2002, c. 133]. Ньюс-релизы, размещаемые на официальных сайтах компаний, учреждений и органов власти, Т.В. Анисимова предлагает называть интернет-релизами [Анисимова, 2015].

В качестве примера интернет-релиза приведем следующую публикацию.

\section{В ПЕРМИ НАЧАЛИ ВЫСАЖИВАТЬ ЦВЕТЫ К ДНЮ ГОРОДА}

Стартовала активная стадия посадки однолетних цветочных культур. Пермь должна заиграть яркими красками к 12 июня.

Площадь цветников в городе составляет более 34 тысяч кв. метров, из них под однолетними цветочными культурами - более 26 тысяч кв. метров. На этой площади будет высажено порядка 820 тысяч однолетних растений.

Площадь под многолетними цветами в этом году будет расширена. Новые цветники появятся в связи с капитальным ремонтом набережной и реконструкцией эспланады. На этих объектах высадят около 12 тысяч многолетних цветочных культур, более 600 кв. метров - хосты, лилейники, астильбы, вероникаструм, а также пользующиеся сейчас популярностью у ландшафтных дизайнеров злаковые культуры.

Планируется высадить 20 разных видов однолетних цветочных культур. Треть цветников займут разные виды и сорта петуний. Также будут высажены любимые пермяками бархатцы, сальвии, цинерарии и другие. Для украшения города используются культуры, которые хорошо себя чувствуют в городской среде и имеют достаточно долгий период цветения, они будут радовать жителей города вплоть до заморозков.

Высадка цветов идет на Комсомольской площади, в Театральном саду, на эспланаде, на площади Гайдара, в сквере им. Мичурина и т. д. Первым с посадками в этом году закончил Индустриальный район.

Самый большой цветник на Средней дамбе будет посвящен Году культуры. Его оформят в виде арфы. Сегодня подрядная организация готовит разбивку этого цветника.

Самыми протяженными станут цветники в Кировском районе по улице Маршала Рыбалко. Там появится около 1 тысячи кв. метров однолетников.

- В этом году у нас все цветники будут более яркими - в красных, желтых, голубых, ярко-розовых тонах. В Год культуры хочется создать больше красоты и пышности, - отмечает главный садовник Перми Илюса Збруева.

Дополнительная информация для СМИ:

Екатерина Гаспер -

212-62-90 (В Перми начали высаживать...).

С одной стороны, текст интернет-релиза содержит много цифровой информации, что характерно для жанра публичного отчета, с другой - в нем употребляются метафоры и другие средства словесной образности разной степени выразительности (стартовала активная стадия, заиграть яркими красками), а также лексика с эмоционально-экспрессивной окраской и семантикой интенсивности (новые, популярностью, любимьге, радовать, самьй большой, более яр$\kappa и м и)$. За счет этих средств формируется положительная тональность текста. Официальный характер информации в пресс-релизе поддерживается завершающим текст указанием фамилии и имени, а также номера телефона специалиста PR-службы, к которому представители СМИ могут обратиться за 
дополнительной информацией. При этом текст пресс-релиза, как правило, сопровождается на сайте фото-, аудио-, видеоматериалами и гиперссылками. Таким образом, можно сказать, что пресс-релиз близок жанру отчета, однако при этом имеет черты публицистичности и рекламности, сочетая новостные фрагменты (сообщения о происходящих событиях) и анонсирующие (превентивные сообщения о том, что еще планируется сделать администрацией для озеленения города).

\section{Информационные материаль}

Документы этого жанра информационной направленности могут исходить от органа исполнительной власти. Составители условно называют эти тексты информационными или методическими материалами, акцентируя тем самым внимание на их неправовом характере. По-видимому, в сфере права жанровая принадлежность текста особенно значима в том случае, если он имеет юридическую силу, юридический статус, то есть является документом в узком понимании этого термина. Все, что находится за пределами нормативной коммуникации, не требует жесткой жанровой отнесенности.

Предлагаем в качестве рабочего следующее определение этого текстотипа: информационные материалы - информационно-справочный жанр письменного делового общения, имеющий целью адаптацию нормативно-правовой информации, ее популяризацию, а также - дополнительно - инструктирование адресата о том, как совершить установленные законом действия и процедуры и достичь определенного результата. Информационные материалы оформляются обычно в виде красочной брошюры - объемного (по ГОСТ - до 48 страниц, фактически - и больше) издания в мягкой обложке (ГОСТ 7.60-2003).

Тексты описываемого жанра составляются непосредственно специалистами органов исполнительной власти или - по заказу экспертами некоммерческих организаций. Строгой адресации текст, как правило, не имеет: информационные материалы адресованы активным гражданам и инициативным группам граждан, что, в частности, отраже- но в названии одной из таких брошюр: Для активных жителей. Опыт и рекомендации (Шомина).

Следует особо отметить, что информационные материалы направлены на повышение уровня правовой грамотности граждан, то есть с помощью этих изданий органы исполнительной власти осуществляют свою первичную функцию - исполнение законов и реализацию государственной политики. Иными словами, основными коммуникативными интенциями составителя текста являются популяризация, объяснение положений законодательства, закрепляющих правила поведения людей и порядок выполнения юридически значимых действий. Думается, можно провести аналогию информационных материалов с научно-популярными текстами, в которых реализуется такая дополнительная задача коммуникации, как «“перевод” специальной научной информации на язык неспециального знания... для широкой аудитории» [Кириченко, 2003, с. 236].

Этот информационный продукт составляется таким языком, который понятен людям, не участвующим в сфере государственного управления. Тексты информационных материалов имеют нестандартную, нетипичную для деловых бумаг форму; в них используются разнообразные вербальные и визуальные средства выражения содержания: нумерованные или маркированные списки, вопросно-ответные комплексы, таблицы, диаграммы, блок-схемы, инфографика, шрифт, цвет, макетирование и др. В качестве примера рассмотрим фрагмент из брошюры «Азбука для потребителей услуг ЖКХ», размещенной на официальном сайте администрации города Волгограда (см. рис. 1).

Как видим, после заголовка-вопроса в первом абзаце констатируется статус общего собрания собственников жилья; отдельной рубрикой ВАЖНО ЗНАТЬ! в рамке оформлена значимая информация; специальной цветной выноской сделана ссылка на нормативный документ - Жилищный кодекс РФ; рубрицированным списком представлены полномочия общего собрания собственников жилья.

Мы разделяем мнение Н.Ф. Пономарева о том, что в жанре информационных материалов более других проявляется «под- 


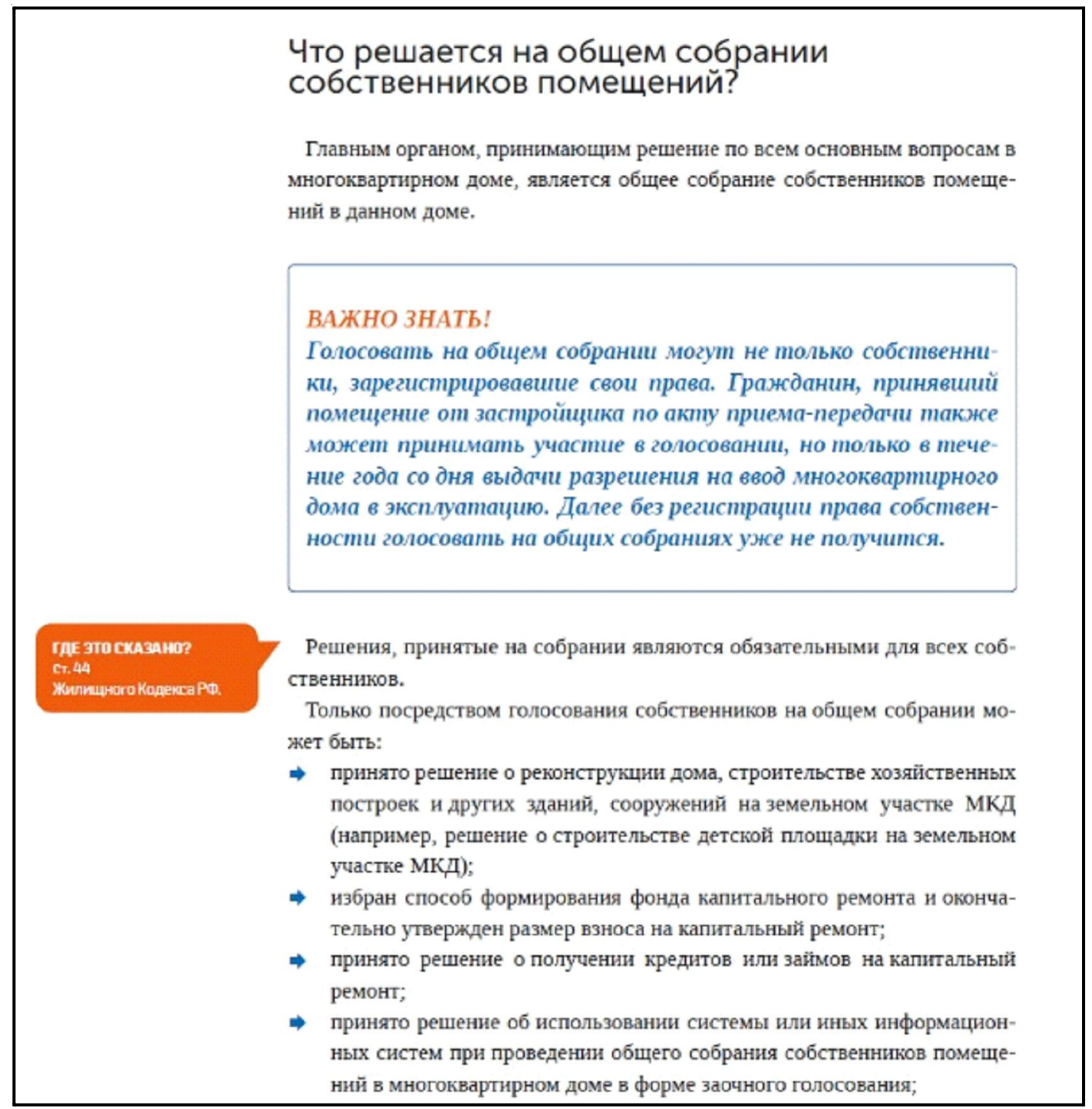

Рис. 1. «Азбука для потребителей услуг ЖКХ». Фрагмент брошюры

Fig. 1. “ABC Guide for Getting Public Utilities Services”. Fragment of a brochure

стройка под мировоззрение и коммуникативные навыки целевой группы» [Пономарев, 2007 , с. 89]. На наш взгляд, это сближает информационные материалы с научно-популярными и рекламными текстами. Как и в рекламной сфере, составители стараются сделать содержание информационных материалов и доступным, и привлекательным для адресата. Приведем примеры графических элементов, особенно ярко иллюстрирующих такую специальную подстройку под потребителя (см. рис. 2, 3).

Примеры показывают, что графические материалы, ориентированные на особые целевые группы (например, детей, их родителей и т. д.), могут сопровождаться элементами со- циальной рекламы: Следите за исправностью приборов!

В использовании визуальных элементов в информационных материалах и жанре публичного отчета обнаружены отличия: в отчете, имеющем выраженный аналитический характер, цифровая информация и графические компоненты, как правило, отражают тенденции развития социальных явлений, закономерные изменения показателей по определенным параметрам; в информационных материалах, имеющих целью разъяснить правовую информацию, изложить ее доступным языком, графика служит упрощению восприятия данных, их адаптации для широкой аудитории. 
М.А. Ширинкина. Информационный тип документов исполнительной власти

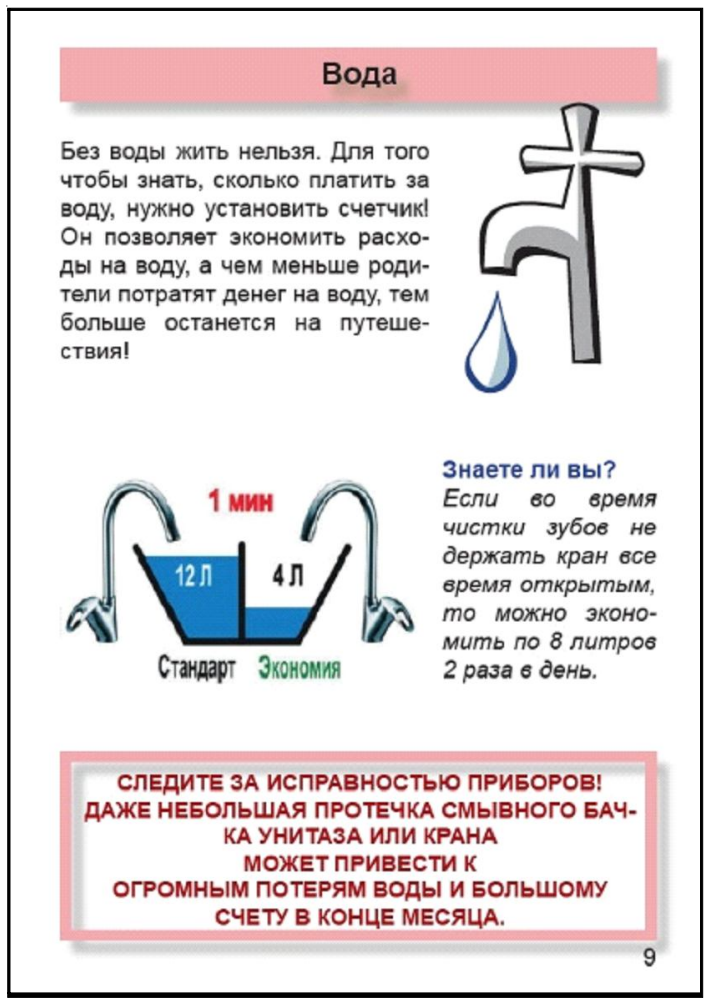

Рис. 2. «ЖКХ для детей» (с. 9)

Fig. 2. "Public Utilities Service for Children" (p. 9)

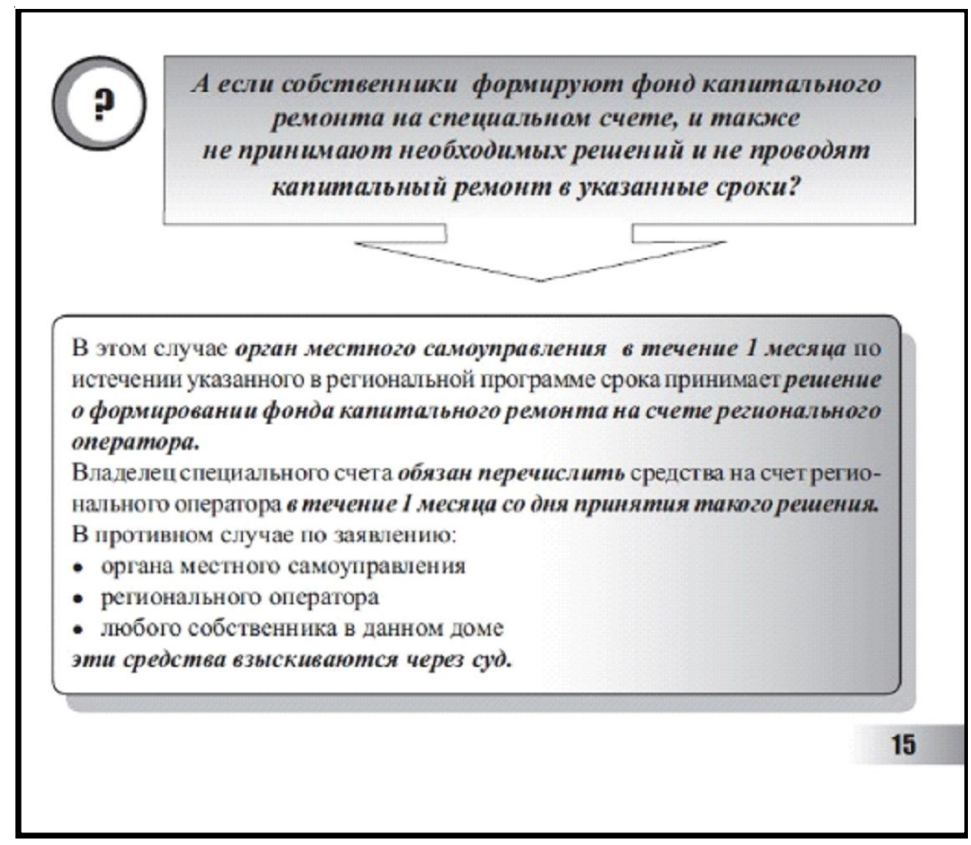

Рис. 3. «Вопросы организации капитального ремонта общего имущества в многоквартирных домах» (с. 15)

Fig. 3. "Issues of Overhaul Repairs of Common Property Multi-Storey Blocks" (p. 15) 
Отдельные фрагменты этих информационных текстов имеют инструктивную направленность: в них указываются алгоритмы выполнения правовых действий и используются глаголы в форме повелительного наклонения, что нехарактерно даже для жанров, формирующих ядро документов императивного типа, - указа, распоряжения, приказа.

\section{Выводы}

Информационный тип текстов исполнительной власти отличается жанровым многообразием. Это детерминируется прежде всего разнообразием частных коммуникативных интенций их составителей: в них проявляются собственно информирование, сообщение, анализ и обобщение, просвещение, популяризация, создание позитивного имиджа власти и т. д.

Все эти тексты имеют официальный характер, то есть исходят от уполномоченных органов исполнительной власти, реализуя тем самым ее основную функцию - исполнение законов.

Содержание информационного типа документов исполнительной власти практически совпадает с содержанием директивных и регламентирующих жанровых разновидностей: в них сообщается о правилах поведения в определенной правовой ситуации, последовательности выполнения юридически значимых действий, событиях в сфере государственной власти и управления, деятельности должностных лиц.

Жанры публичного отчета, пресс-релиза и информационных материалов имеют сходства и отличия. Отчету присуща явная аналитическая направленность, информация, представленная в нем, оказывается вторичной, составленной на основе аналитико-синтетических механизмов переработки исходных сведений; основная цель составителя отчета сообщить о действиях, которые должностное лицо или орган власти уполномочен совершать в соответствии с законодательством. При этом текст характеризуется высокой степенью официальности и стандартизованности.

Пресс-релиз при доминировании информативной функции в качестве сопутствующей выполняет и функцию воздействия - формирует общественное мнение о представителях власти. Посредством положительно окрашен- ной лексики в нем оперативно сообщается о позитивных аспектах деятельности властных структур. Композиция пресс-релиза относительно устойчива, но допускает творческое наполнение каждой части.

Информационные материалы призваны реализовать функцию просвещения - популярно представить правовую информацию, адаптировать ее для широкого адресата. Доступность, понятность изложения достигаются за счет использования различных форм наглядности и схематизации материала. Имея дополнительную инструктивную направленность, тексты информационных материалов отличаются нетипичными для деловой сферы общения вербальными и невербальными средствами.

Перспективным представляется детальное изучение перечисленных выше жанровых разновидностей информационного типа письменного дискурса исполнительной власти в категориально-текстовом аспекте, что, по нашему мнению, позволит наиболее рельефно выделить индивидуальные особенности репрезентации основных текстовых категорий (тональности, авторизации, адресации, темы и композиции) в каждом конкретном жанре.

\section{ПРИМЕЧАНИЕ}

${ }^{1}$ Исследование выполнено при финансовой поддержке гранта РФФИ, проект 17-29-09158 офи_м «Создание корпуса официально-деловых текстов русского языка (ОДКРЯ)».

The research was funded by Russian Foundation for Basic Research, project number 17-29-09158 ofi_m "Creating the Russian official-legislative texts corpus".

\section{СПИСОК ЛИТЕРАТУРЫ}

Анисимова T. В., 2015. Специфика PR-жанров в Интернете // Вестник Волгоградского государственного университета. Серия 2, Языкознание. № 4 (28). C. 129-137. DOI: http://dx.doi.org/ 10.15688/jvolsu2.2015.4.16.

Анисимова Т. В., 2018. Жанры социальной рекламы // Вестник Волгоградского государственного университета. Серия 2, Языкознание. T. 17, № 1. C. 160-171. DOI: https://doi.org/ 10.15688/jvolsu2.2018.1.17.

Бахтин М. М., 1986. Проблема речевых жанров // Эстетика словесного творчества. М. : Искусство. C. 250-296. 
Белоконева К. А., 2012. Стратификация документов сферы государственного управления образованием : автореф. дис. ... канд. филол. наук. Волгоград. 22 с.

Богоявленский А. Е., 2004. Типы текстов паблик рилейшнз и носители ПР-сообщений // Вестник Воронежского государственного университета. Серия: Филология. Журналистика. № 1. C. $150-157$.

Буслаева Е. С., 2015. Документные средства сферы связей с общественностью: типология, свойства, стилевая организация : автореф. дис. ... канд. филол. наук. Волгоград. 25 с.

Быстрова А. С., 2017. Жанровые параметры стратегии как документа долгосрочного планирования // Вестник Волгоградского государственного университета. Серия 2, Языкознание. Т. 16, № 3. С. 199-206. DOI: https://doi.org/ 10.15688/jvolsu2.2017.3.20.

Илатовская Э. А., 2007. Информационная политика органов исполнительной власти субъекта Российской Федерации: формирование и проблемы реализации : автореф. дис. ... канд. полит. наук. СПб. 22 с.

Имшинецкая И. А., 2002. Жанры печатной рекламы, или Сундук с идеями копирайтера. М. : РИП-холдинг. $130 \mathrm{c}$.

Киреева Е. 3., 2015. Эпистемическая модальность в информационных документах (на материале регионального законодательства) // Юрислингвистика. № 4 (15). С. 16-19.

Кириченко Н. В., 2003. Научно-популярный подстиль // Стилистический энциклопедический словарь русского языка / под ред. М. Н. Кожиной. М. : Флинта : Наука. С. 236-242.

Кривоносов А. Д., 2002. PR-текст в системе публичных коммуникаций. СПб. : Петербург. востоковедение. 288 с.

Куняев Н. Н., Уралов Д. Н., Фабричнов А. Г., 2012. Документоведение. М. : Логос. 352 с.

Кушнаренко Н. Н., 2006. Документоведение. Киев : Знания. $459 \mathrm{c.}$

Кушнерук С. П., 2008. Документная лингвистика. М. : Флинта : Наука. 256 с.

Мозолин А. В., 2012. Информационная политика органов власти // Российская школа связей с общественностью. Вып. 4. С. 4-62.

Пономарев Н. Ф., 2007. Информационная политика органа власти: пропаганда, антипропаганда, контрпропаганда. Пермь : Изд-во Перм. гос. техн. ун-та. 183 с.

Тихомирова А. В., 2008. Коммуникативная специфика пресс-релиза как разновидности PR-текстов (на материале испанского языка) // Вестник РУДН. Серия «Вопросы образования: языки и специальность». № 2. С. 61-67.
Ширинкина М. А., 2017. Документы исполнительной власти в функционально-стилистической системе русского языка // Известия Уральского федерального университета. Серия 2, Гуманитарные науки. Т. 19. № 2 (163). C. 134-146. DOI: 10.15826/izv2.2017.19.2.030.

\section{ИСТОЧНИКИ И СЛОВАРИ}

В Перми начали высаживать... - В Перми начали высаживать цветы к Дню города. URL: http:// www.gorodperm.ru/news/2596-rubric/2019/05/ 30/50127-id (дата обращения: 25.06.2019).

ГОСТ 7.60-2003-ГОСТ 7.60-2003. Издания. Основные виды. Термины и определения. Введ. 2004-07-01. М. : Изд-во стандартов, 2004. 36 с.

Информационный бюллетень... - Информационный бюллетень Администрации Санкт-Петербурга № 18 (1117) от 20.05.2019. URL: https:// www.gov.spb.ru/static/writable/mediact/ bulletin/2019/05/17/\%D0\%98\%D0\%91-0520.pdf (дата обращения: 25.06.2019).

Словарь видов... - Словарь видов и разновидностей современной управленческой документации /Ф. В. Янковая [и др.]. М. :ВНИИДАД, 2014. 81 с.

Состояние и результативность... - Состояние и результативность системы образования города Архангельска в 2017-2018 учебном году : информ.-аналит. сб. Архангельск : [б. и.], 2018. 115 c. URL: http://www.arhcity.ru/data/1067/ ES17-18.pdf (дата обращения: 25.06.2019).

Управление... - Управление многоквартирными домами. В помощь собственнику. Пермь : [б. и.], $2013.60 \mathrm{c}$.

Шомина -Шомина Е.С. Для активных жителей. Опыт и рекомендации. Пермь : ОТ и ДО, 2009. 32 с.

Азбука для потребителей услуг ЖКХ. Выпуск 2.0. URL: http://www.volgadmin.ru/d/branches/gkh/ azbuka (дата обращения: 25.06.2019).

Вопросы организации капитального ремонта общего имущества в многоквартирных домах. Пермь : [б. и.], 2013. 60 с.

Государственная система правовой информации : офиц. интернет-портал правовой информ. URL: http://pravo.gov.ru (дата обращения: 25.06.2019).

ЖКХ для детей. Пермь : [б. и.], 2016. 16 с.

Справочно-правовая система «КонсультантПлюс». URL: http://www.consultant.ru (дата обращения: 25.06.2019).

\section{REFERENCES}

Anisimova T.V., 2015. Spetsifika PR-zhanrov v internete [On Specificity of PR-Genres in the Internet]. 
Vestnik Volgogradskogo gosudarstvennogo universiteta. Seriya 2, Yazykoznanie [Science Journal of Volgograd State University. Linguistics], no. 4 (28), pp. 129-137. DOI: http:// dx.doi.org/10.15688/jvolsu2.2015.4.16.

AnisimovaT.V., 2018. Zhanry sotsialnoy reklamy [Genres of Social Advertising]. Vestnik Volgogradskogo gosudarstvennogo universiteta. Seriya 2, Yazykoznanie [Science Journal of Volgograd State University. Linguistics], vol. 17, no. 1, pp. 160-171. DOI: https://doi.org/10.15688/jvolsu2.2018.1.17.

Bakhtin M.M., 1986. Problema rechevykh zhanrov [The Problem of Speech Genres]. Estetika slovesnogo tvorchestva [Aesthetics of Verbal Creativity]. Moscow, Iskusstvo Publ., pp. 250-296.

Belokoneva K.A., 2012. Stratifikatsiya dokumentov sfery gosudarstvennogo upravleniya obrazovaniem: avtoref. dis. ... kand. filol. nauk [Stratification of Documents in the Sphere of State Government Education. Cand. philol. sci. abs. diss.]. Volgograd. $22 \mathrm{p}$.

Bogoyavlenskiy A.E., 2004. Tipy tekstov pablik rileyshnz i nositeli PR-soobshcheniy [PR-Texts Types and PR-Messages Exponents]. Vestnik Voronezhskogo gosudarstvennogo universiteta. Seriya: Filologiya. Zhurnalistika [Proceedings of Voronezh State University. Series: Philology. Journalism], no. 1, pp. 150-157.

Buslaeva E.S., 2015. Dokumentnye sredstva sfery svyazey s obshchestvennostyu: tipologiya, svoystva, stilevaya organizatsiya: avtoref. dis. ... kand. filol. nauk [Documentary Means of Public Relations: Typology, Properties, Style Organization. Cand. philol. sci. abs. diss.]. Volgograd. $25 \mathrm{p}$.

Bystrova A.S., 2017. Zhanrovye parametry strategii kak dokumenta dolgosrochnogo planirovaniya [Genre Parameters of Strategy as a Document of Long-Term Planning]. Vestnik Volgogradskogo gosudarstvennogo universiteta. Seriya 2, Yazykoznanie [Science Journal of Volgograd State University. Linguistics], vol. 16, no. 3, pp. 199-206. DOI: https://doi.org/10.15688/ jvolsu2.2017.3.20.

Ilatovskaya E.A., 2007. Informatsionnaya politika organov ispolnitelnoy vlasti subyekta Rossiyskoy Federatsii: formirovanie i problemy realizatsii: avtoref. dis. ... kand. polit. nauk [Information Policy of the Executive Branch of the Russian Federation: The Formation and Implementation Problems. Cand. polit. sci. abs. diss.]. Saint Petersburg. 22 p.

Imshinetskaya I.A., 2002. Zhanry pechatnoy reklamy ili sunduk s ideyami kopiraytera [Genres of
Print Advertising, or the Chest with the Ideas of the Copywriter]. Moscow, RIP-kholding Publ. $130 \mathrm{p}$.

Kireeva E.Z., 2015. Epistemicheskaya modalnost v informatsionnykh dokumentakh (na material regionalnogo zakonodatelstva) [Epistemic Modality in Documents Information (Based on the Regional Legislation)]. Yurislingvistika [Legal Linguistics], no. 4 (15), pp. 16-19.

Kirichenko N.V., 2003. Nauchno-populyarnyy podstil [Popular Science Sub-Style]. Stilisticheskiy entsiklopedicheskiy slovar russkogo yazyka [The Stylistic Encyclopaedic Dictionary of the Russian Language]. Moscow, Flinta Publ., Nauka Publ., pp. 236-242.

Krivonosov A.D., 2002. PR-tekst v sisteme publichnykh kommunikatsiy [PR Text in the System of Public Communication]. Saint Petersburg, Peterburgskoe Vostokovedenie Publ. 288 p.

Kunyaev N.N., Uralov D.N., Fabrichnov A.G., 2012. Dokumentovedenie [Document Science]. Moscow, Logos Publ. 352 p.

Kushnarenko N.N., 2006. Dokumentovedenie [Document Science]. Kiev, Znaniya Publ. 459 p.

Kushneruk S.P., 2008. Dokumentnaya lingvistika [Document Linguistics]. Moscow, Flinta Publ., Nauka Publ. 256 p.

Mozolin A.V., 2012. Informatsionnaya politika organov vlasti [Information Politics of the Authorities]. Rossiyskaya shkola svyazey $s$ obshchestvennostyu [Russian School of Public Relations], iss. 4, pp. 4-62.

Ponomarev N.F., 2007. Informatsionnaya politika organa vlasti: propaganda, antipropaganda, kontrpropaganda [Information Politics of the Authorities: Propaganda, Anti-Propaganda, Counter-Propaganda]. Perm, Izd-vo Permskogo gosudarstvennogo tekhnicheskogo universiteta. $183 \mathrm{p}$.

Tikhomirova A.V., 2008. Kommunikativnaya spetsifika press-reliza kak raznovidnosti PRtekstov (na materiale ispanskogo yazyka) [Communicative Characteristics of Press-Release as Variety of Public Relations Discourse]. Vestnik RUDN. Seriya «Voprosy obrazovaniya: yazyki i spetsialnost», no. 2, pp. 61-67.

Shirinkina M.A., 2017. Dokumenty ispolnitelnoy vlasti $\mathrm{v}$ funktsionalno-stilisticheskoy sisteme russkogo yazyka [Executive Documents in the Functional Styles System of the Russian Language]. Izvestiya Uralskogo federalnogo universiteta. Seriya 2, Gumanitarnye nauki [Izvestia. Ural Federal University Journal. Series 2. Humanities and Arts], vol. 19, no. 2 (163), pp. 134146. DOI: 10.15826/izv2.2017.19.2.030. 


\section{SOURCES AND DICTIONARIES}

$V$ Permi nachali vysazhivat tsvety $k$ Dnyu goroda [In Perm, They Began to Plant Flowers for the City Day]. URL: http://www.gorodperm.ru/news/ 2596-rubric/2019/05/30/50127-id (accessed 25 June 2019).

GOST 7.60-2003. Izdaniya. Osnovnye vidy. Terminy $i$ opredeleniya. Vved. 2004-07-01 [GOST 7.602003. Editions. Basic Type. Terms and Definitions. Introduced July 1, 2004]. Moscow, Izd-vo standartov, 2004. $36 \mathrm{p}$.

Informatsionnyy byulleten Administratsii SanktPeterburga № 18 (1117) ot 20.05.2019 [Newsletter of the Administration of Saint Petersburg no. 18 (1117), of May 20, 2019]. URL: https:/www.gov.spb.ru/static/writable/mediact/ bulletin/2019/05/17/\%D0\%98\%D0\%91-0520.pdf (accessed 25 June 2019).

Yankovaya F.V. et al., eds. Slovar vidov i raznovidnostey sovremennoy upravlencheskoy dokumentatsii [Dictionary of Types and Varieties of Modern Management Documentation]. Moscow, VNIIDAD, 2014. $81 \mathrm{p}$.

Sostoyanie $i$ rezultativnost sistemy obrazovaniya goroda Arkhangelska v 2017-2018 uchebnom godu: inform.-analit. $s b$. [The State and Performance of the Education System of the City ofArkhangelsk in the 2017-2018 Academic Year. Information and Analytical Collection].
Arkhangelsk, [s. n.], 2018. 115 p. URL: http:// www.arhcity.ru/data/1067/ES17-18.pdf (accessed 25 June 2019).

Upravlenie mnogokvartirnymi domami. V pomoshch sobstvenniku [Management of Apartment Buildings. To Help the Owner]. Perm, [s. n.], 2013. $60 \mathrm{p}$.

Shomina E.S. Dlya aktivnykh zhiteley: Opyt $i$ rekomendatsii [For Active Residents: Experience and Recommendations]. Perm, OT i DO Publ., 2009. 32 p.

Azbuka dlya potrebiteley uslug ZhKKh. Vypusk 2.0. [ABC Guide for Getting Public Utilities Services. Release 2.0]. URL: http://www.volgadmin.ru/d/ branches/gkh/azbuka (accessed 25 June 2019).

Voprosy organizatsii kapitalnogo remonta obshchego imushchestva $v$ mnogokvartirnykh domakh [Issues of Overhaul Repairs of Common Property Multi-Storey Blocks]. Perm, [s. n.], 2013. 60 p.

Gosudarstvennaya sistema pravovoy informatsii: ofits. internet-portal pravovoy inform. [State System of Legal Information. Official Online Portal of Legal Information]. URL: http:// pravo.gov.ru (accessed 25 June 2019).

ZhKKh dlya detey [Public Utilities Service for Children]. Perm, [s. n.], 2016.16 p.

Spravochno-pravovaya sistema «KonsultantPlyus» [Reference Legal System "KonsultantPlyus"]. URL: http://www. consultant.ru (accessed 25 June 2019).

\section{Information About the Author}

Mariya A. Shirinkina, Candidate of Sciences (Philology), Associate Professor, Department of Russian Language and Stylistics, Perm State National Research University, Bukireva St, 15, 614990 Perm, Russia,m555a@yandex.ru, https://orcid.org/0000-0002-6951-0653

\section{Информация об авторе}

Мария Андреевна Ширинкина, кандидат филологических наук, доцент кафедры русского языка и стилистики, Пермский государственный национальный исследовательский университет, ул. Букирева, 15, 614990 г. Пермь, Россия, m555a@yandex.ru, https://orcid.org/0000-0002-6951-0653 